\title{
The Eu Facing New Energy Challenges: Crevasses to Its Performance as a Single Actor?
}

\author{
Vasileios Balafas $^{1}$, Efstathios T. Fakiolas ${ }^{2}$ \\ ${ }^{1,2}$ University of the Peloponnese / Dept of Political Science and International Relations \\ 11vbalafas@uop.gr, ${ }^{2}$ fakiolas@uop.gr / 1 Aristotelous St. \& Athinon Ave, Corinth, \\ Greece
}

\begin{abstract}
The mid-2010s brought about a considerable realignment to the global energy landscape. Since then, the shale revolution has enabled the US to pursue a net-exporter status, resulting in a continuous crude exports growth into Europe and Asia. Russia has been forced to cooperate with OPEC and create an "OPEC plus" schema, in order to react both to the meteoric fall of oil prices in 2015 and 2016 and to market share losses from the non-OPEC supply growth. China has started looking for an upgraded role in the international arena via a grid of bilateral and regional energy strategies. Brazil and India have also been pushed to engage in the energy play. The EU, during three crises, among such other crucial issues that tend to jeopardize its cohesion, as a sovereign debt crisis, the "Brexit" and the migration crisis, stays focused on the creation of an "Energy Union" and the pervasive implementation of the Third Energy Package policy. Yet, a tacit but severe debate emerges internally on a variety of relevant issues, such as shale technologies, the Nord Stream 2 pipeline and Norway's hydrocarbons resources depletion. Focusing on latest energy developments, combined with political ones, the paper argues that the energy field could be another one challenge for the EU's integration and its ability to act globally as a single actor.
\end{abstract}

Keywords: energy, EU, global status, integration, policy

\section{Introduction}

The mid-2010s brought about a considerable realignment to the global energy landscape, especially with regards to oil and natural gas. The shale revolution is commonly pointed out as a "game changer". It has enabled the US to pursue a netexporter status and lift the 40-yearold oil exports ban(Sartori, 2014: 80). US crude exports to Europe averaged 290,000 b/d in 
2017; to Asia keeps growing, developments that seemed unthinkable back in 2013(S\&P Global Platts, 2018: 6-9). Russia has been forced to cooperate with OPEC and its cornerstone Saudi Arabia, creating the "OPEC plus" schema, in order to react both to the meteoric fall of oil prices in 2015 and 2016 and to market share losses from the non-OPEC supply growth(Kapitonov, 2018: 5-6). China has started looking for an upgraded role in the international arena, vividly implementing its "Belt and Road Initiative" policy to the energy field, extending its economic and trading leverage(Gong, 2018: 6-8). It also tries to attenuate its heavy dependence on hydrocarbon energy suppliers via a grid of bilateral and regional strategies(Downie, 2015: 810). It is important to mention that despite its enduring efforts to develop its renewable energy sector, it cannot, for the time being, change the nature of its economy built on hydrocarbon use, particularly on coal(Downie, 2015: 807). Equally important, it wants to downplay its reliance on sea lanes, considered as a thorn in its ambitions(Yilmaz and Daksueva, 2019: 87).

The big picture of the global energy landscape realignment could not disregard the significant rise of states such as Brazil and India. The former is turning into a major oil exporter thanks to important new oil field discoveries, with its state-owned oil firm Petrobras being considered the "crown jewel" of this transition(AFP, 2018). The latter is continuously ameliorating its growth rates. In 2017, it became one of the world's biggest energy investors(Forest, 2017). The simultaneous boosting of the Indian Navy should not be underestimated, especially in nuclear-armed submarines sector(Woody, 2018). The pursuit of a "world-class navy" cannot but be connected to the broader country's strategy on energy supply through sea lanes(Dasgupta, 2018: 15-16).

At the same time, the EU is coming out of a long economic crisis that has challenged its cohesion, with the most current episode being Italy's budgetary dispute. "Brexit" is a clear sign that an "unthinkable" withdrawal from the Union is probable and the migration puzzle seems to put eminent hurdles to EU member-states' solidarity(Batel and DevineWright, 2018: 42). In the energy field, the EU appears to have set forth the creation of a Common Energy Market and the Third Energy Package as pivotal policy tools(Goldthau and Sitter, 2015: 956-957). Yet, a tacit but intense debate going on within EU bodies over shale technologies, while the recent dispute between the EU Commission and the EU Council - and among the member-states about the Nord Stream 2 gas pipeline, demonstrates crevasses to the EU's actorship that can no longer be hidden(Siddi, 2018: 12-13).

Last but not least, the EU's approach to energy issues is quite different from those of its major competitors. It emphasizes regulatory power promoting the creation of an energy community, and in this respect important achievements have already been made(Thaler, 2016: 573-574). However, its regulatory power seems to be more market driven and marginally moving beyond member-states' national interests. In other words, the EU's energy regulatory power might be the catalyst for the emergence of various divergences among its member-states. 
In this context, we assume that a state's energy-related decisions are closely interrelated to its energy security concerns. All other things being equal, the way it tries to conceptualize, synthesize, and streamline the available policy options in order to devise an energy security policy represents an energy security riddle. As energy security is hardly a commonly predefined notion or a linear sequential decision-making process, the riddle concerns not only the policy formulation actions and options but also the perceptions through which energy issues are interpreted. The policy choices and steps that a state makes to reinforce its energy security result from a perceptual palette with regards to what shape and substance an energy security policy should take. Hence, this is the riddle that a state must address before it sets forth an energy security policy. As this paper demonstrates, for each state the answer to the riddle comes out of a different palette mixing. Examining the primary aspirations and moves of some major and rising countries in the energy sector through the lens of the energy security riddle, we discern notable traces of incompatibility. We argue that this incompatibility is likely to cause crevasses to the EU's performance as a single actor facing the new energy challenges at a global level.

\section{The Energy Security Riddle}

The 2010s are landmarked by the shale revolution in the US, which brought a pivotal realignment to the world's fossil fuels production(Dunn and McClelland, 2013). After four decades, the US lifted the crude oil export ban and became the world's top producer of petroleum and natural gas hydrocarbons, quadrupling its liquefied natural gas exports(Doman and Kahan, 2018). An array of earthshaking events, such as the withdrawal of the US from the Paris climate agreement, the 2014-2016 tailspin of oil prices, the spectacular decrease of US oil imports from West Africa, the Middle East and Latin America, all are some of the outcomes of this technological breakthrough(Crooks, 2015). These events coupled with the advent of the so-called "Trump era" resulted in putting the energy production renaissance at the core of a new national aspiration(Moore, 2017).

US President Donald Trump, combining energy security with his "America First" political vision, articulated the "Energy Dominance" doctrine(The White House, 2017). The progress in shale production was more than a mere global energy market parameter. It became the flagship for an all-embracing domestic and foreign policy pointing to a global awareness that the US grows larger as a preponderant great power in the international system(President Speech, 2017).

Overall, theory and experience demonstrate that energy security remains a highly contested concept. Scarcely surprising, Sovacool lists at least 45 different definitions(Sovacool, 2011: 3-6). This list is likely to enlarge. It is indicative that Trump's "Energy Dominance", we claim, adds to the definitional portfolio of energy security the notion of a global carrier who, through exports, might secure its allies against any energy threat. Trump makes it pretty clear: "we're going to be an exporter - 
exporter. We will be dominant. We will export American energy all over the world, all around the globe. These energy exports will create countless jobs for our people, and provide true energy security to our friends, partners, and allies all across the globe."(President Speech, 2017).

Alongside goes the inclusion of the concept of threat in the energy jargon. Nowadays, NATO, for instance, which more often draws on "hybrid threats" and "hybrid warfare"(Abbott, 2016: 4-19), has since the Ukraine crisis of 2014 considered of energy as a hybrid threat(Rühle, 2015). Although energy security had captured its attention since the beginning of the 2000s, it was not until 2010 that it formally earned a place in its security and strategic agenda(Rühle, 2012). As in the Ukrainian case, Russia's assertive stance and the EU's high reliance on Russian gas supplies were once again the main reason behind this development. As underlined later in a NATO publication, energy was "a tool which Russia has been actively using in Europe to gain influence, and to divide and rule, has been its economic leverage including through the exploitation of energy dependence"(Larsen et al., 2015: 223).

Therefore, the EU's energy dependence on Russian supplies is a major factor of insecurity. From a market perspective, however, energy dependence is in fact bidirectional, in the sense that the supplier is also at risk once it is too committed to the buyer. It is for that reason that interdependence is argued to be an optimal answer to energy security concerns(Krickovic, 2015: 19-21). But this seems rather utopian because, as aptly underscored, "while the market can provide energy supply, it does not create energy security."(Stergiou, 2017: 261).

There is no denying that energy is much more than a simple commodity. It is closely intertwined with national interest, power antagonism, international conflicts and the position of a state in the global political order(Goldthau and Sitter, 2015: 943).

As energy is seen as a strategic good so are such energy-related elements natural resources, trade, technology, growth, development and national capabilities. By extension, energy is an overall factor of national power that might be maximized and protected in many conventional and hybrid ways to serve a state's security purposes. To encapsulate this meaning, we introduce the term "energy status goal", which is best illustrated in Trump's words: “American energy will power our ships, our planes and our cities. American hands will bend the steel and pour the concrete that brings this energy into our homes and that exports this incredible, newfound energy all around the world. And American grit will ensure that what we dream, and what we build, will truly be second to none. We will be number one again all the way. We're going to make America great again."(President Speech, 2017).

Energy status is the next higher level to the accomplishment of energy security and energy availability. The US, for instance, has proved so far able to achieve and maintain energy status, labeled "Energy Dominance", owing to the shale revolution, which has made it possible for it to reduce hydrocarbons resources imports, increase its own oil and gas production and exports and enhance its domestic energy security. In essence, this 
status represents the capability of the US to capitalize on its energy resources to tame the energy market and safeguard friends and allies against energy related threats.

In short, experience shows that the formulation of a state's energy security policy and the actions that it takes, called strategies, goes through a dynamic and nonpredetermined decisions path. It draws on, and concurrently constitutes, five consecutive stages or pillars of a continuing and advancing process (Fig.1). Each of these stages adds its own attributes and parameters that altogether combined lead to a distinct perception through which each state designs its energy security policy. This implies that as a whole this process may result in various policy outcomes. In effect, before a state determines its energy security policy, it should in advance perceive of international and domestic conditions and accordingly figure out which stages it seeks to go through, in order to achieve its own energy security goal. This decision and ensuing actions are the answer that a state gives to the energy security riddle facing.

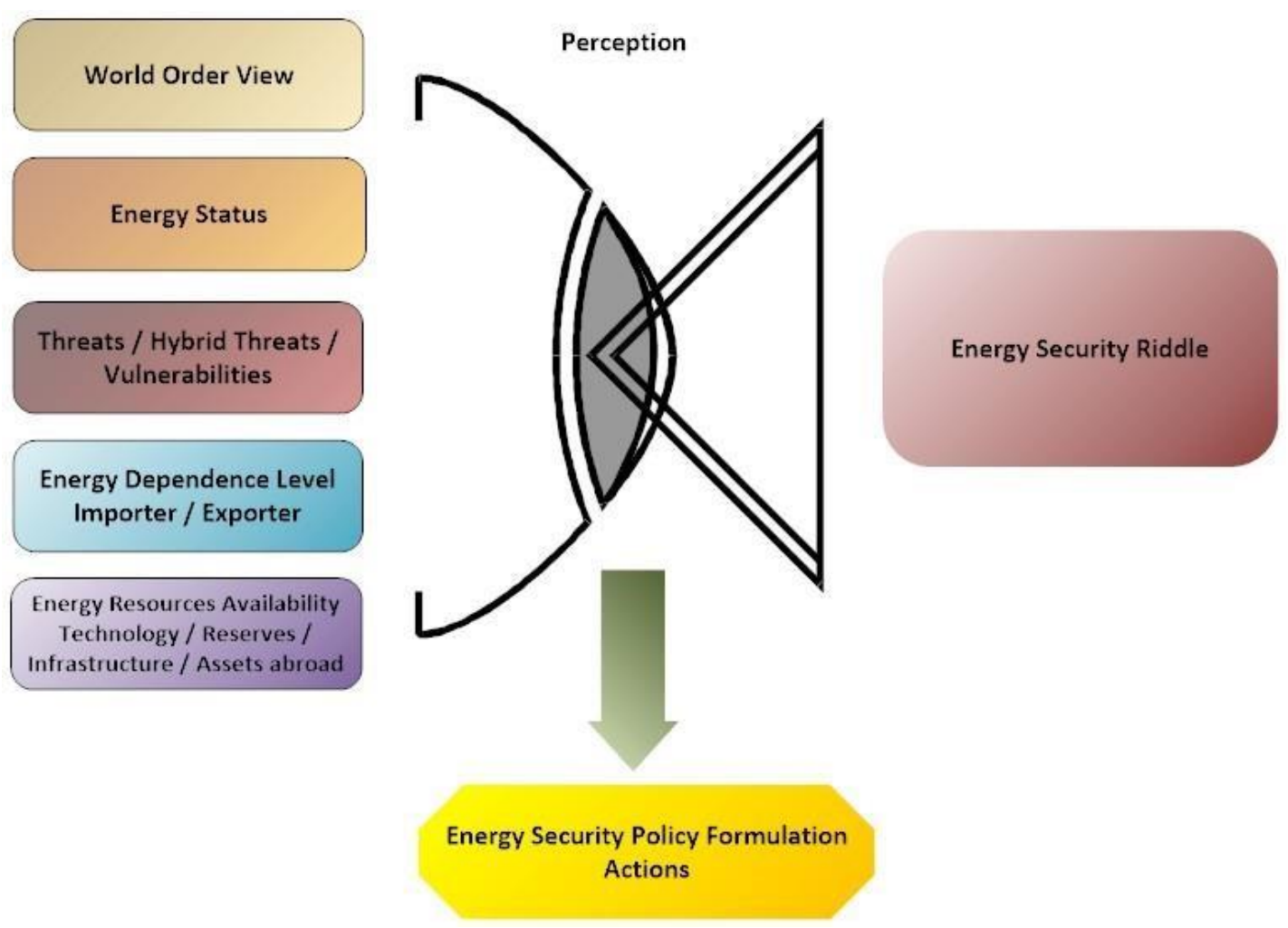

Fig. 1 A state's perception of the Energy Security Riddle

Likewise, the Russian case can thoroughly be explored and explained through this analytical lens. In the 2000s Russia, having vast energy resources, and a well-established 
pipelines network, started looking for a better international power status(Charokopos and Dagoumas, 2018). Its capability to produce energy (oil \& gas) evolved into the main driver of this effort, and the national narrative pointed to a forceful aspiration to become an "energy superpower"(Proedrou, 2018). President Vladimir Putin's vision to reestablish Russia's national glory and pride goes through with the optimization of Russia's energy exporting performance(Rutland, 2015). This is the energy security riddle from the perspective of an exporting country that draws its economy upon export revenue. For example, the shale revolution and the plunge of oil prices during 20142016 was a serious blow for the OPEC countries and Russia. As many non-OPEC countries, such as Brazil and Canada, experienced a remarkable oil production rise, the stake for traditional major exporters was twofold(Behar and Ritz, 2016: 16-19). On one hand, they should strive to sustain their market share. On the other, they should find a way to maintain prices at viable levels for their economies(The Economist, 2014). Hence, the early December 2016 agreement was concluded to reduce oil production by the OPEC member states and 11 non-OPEC countries such as Russia, Azerbaijan, Oman, Mexico, Malaysia, Sudan, South Sudan and Bahrain(BBC news, 2016). The new OPEC scheme expanded to 24 members, and today is known as the "OPEC+", led by Saudi Arabia and Russia(Cohen, 2018). The following sentence dawn from the official statement of the 175th Meeting of OPEC, in Vienna, on the $6^{\text {th }}$ of December 2018 is indicative of the notion of "energy security" from the producers' side: “focus on fundamentals for a stable and balanced oil market, in the interests of producers, consumers, and health and sustainability of the petroleum industry."(OPEC, 2018). In fact, this position echoed the words of HE Abdalla Salem El-Badri, OPEC Secretary General: "energy security should be reciprocal. It is a two-way street. Security of demand is as important to producers, as security of supply is to consumers"(OPEC, 2008).

In an international system led by the US's supremacy, therefore, Russia's effort to use its abundant energy resources to ameliorate its state power status has resulted in the politicization of energy politics(Kratochvíl and Tichý, 2013: 391). This development is critical for understanding EU's ambivalent stance on energy issues. As some scholars claim, the EU's energy security strategies appear to have been decisively dictated by a consideration that Russia is an unreliable, but indispensable energy supply partner(Proedrou, 2017: 2-4). Before we examine how this ambiguity results from the different energy status goals of EU member-states, let us focus on the energy priorities of such newly emerging states in the energy field as China, Brazil and India.

\section{Rising States and Energy Security Policy}

The realignment to the global energy landscape owns much to the advent of newcomers to the field. China, Brazil and India are the main rising powers that throughout the 2010 s evidently strive to improve their position in the international system, looking for a world order from their own point of view(Christensen and Xing, 
2016). While they have made a remarkable economic and military progress, they also possess the resources to better their power status(Ghimire, 2018: 1). Their moves in the energy field show the link between energy resources and a state's ability to pursue an upgraded international role.

The rise of China is considered as the most important enabling force of developments and transformations in the international system in coming decades and its energy related interests may be indicative of its overall motives and strategies(O'Sullivan, 2017: 248). In fact, China's "need to secure energy has been one of the single largest drivers of its foreign policy over the last two decades."(O'Sullivan, 2017: 214). China failed to achieve "shale revolution" during 2013-2014 in order to exploit its own domestic resources(Skalamera, 2018: 102). In 2018, it became the world's largest importer of oil, gas and coal and, thus, its energy security priorities coupled with its all aspirations and peculiarities, are very interesting from the viewpoint of a net- energy importing(Jaganathan, 2018). Having an assertively trade export-led economy engaged in highly competitive world markets, China urgently looks for low cost energy; and this is one basic reason behind its late detachment from coal(Locatelli et al., 2017: 163). Furthermore, its approach to energy issues is a mercantilist one. Ensuring national control over supplies, supply diversification, safe transport routes and national ownership of resources abroad, all are its primary interests while supply isolation and US control of sea being the main threats(Lind and Press, 2018: 201-204).

These energy security concerns have led China to set forth a multifarious action plan that can be summarized in five basic dimensions. First, China prefers bilateral and regional deals to global or multilateral initiatives, as it believes that the US commands world politics(Downie, 2015: 806-809). Second, this preference, embedded as it is in a nationalistic attitude, pervades its Belt and Road Initiative (BRI) strategy with regards to energy issues(Reeves, 2018). Third, owing to its preference for low gas prices and gas pipeline sources because of its fear of US controlled shipping routes, China, though delayed for 15 years, has recently signed a 30-year gas supply agreement with Russia(Skalamera, 2018: 96). Fourth, China continues to develop its naval forces and reinforce its presence in the South China Sea and the Indian Ocean, in order to protect its national interests in crucial territorial zones and sea lanes(Zhao, 2008: 219-221). Fifth, China heavily invests in innovative technologies to develop traveling-wave nuclear reactors for its energy needs(Karlsson, 2018: 6). In this sector there exists close cooperation with Russia. It is reported that "two-thirds of the new reactors under construction worldwide are estimated to be using designs from China and Russia"(Ichord, 2018). Last but not least, several analysts argue that China and Russia take issue with current structure of the international system and as they both seek to curtail the US dollar's hegemony in global economy(Yilmaz and Daksueva, 2019: 6671). This doesn't imply that China and Russia are totally aligned, as China wants to contain both Russia's and US' influence in Central Asia, aspiring to a multipolar world(Smith Stegen, 2015: 199). For China the energy security riddle goes hand by hand 
with its distrust of the global status quo and its effort to play the role that China believes it deserves(Kennedy, 2015: 47-50).

Brazil, after the US shale revolution, has evolved into one of the most important factors of the ongoing realignment of the global energy landscape. Latest energy resources discoveries are expected to pave the way for Brazil to experience its own "oil boom' that will increase its budget revenues(Paraskova, 2018) and turn into the world's sixth oil exporter by 2035(Downie, 2015: 801). Today, too, it possesses the three largest natural gas reserves in the region while being a leading natural gas consuming country in Latin America(Sookhan, 2018).

In the 2010s, therefore, Brazil proves able to dynamically show up in energy markets on its way to becoming a global player(Gardini and Almeida, 2016: 1). Contrary to China's lonely international trajectory, Brazil stakes a claim to a better world status by pursuing both to evolve into the leader of the WTO's developing states and, in cooperation with India, to play a pioneering role in the G20 group, the world's largest economies(Hopewell, 2015). Since the 2000s, Brazil has used its energy sector as tool to improve its economic performance and foreign policy influence by adopting a moderate cooperative attitude. In this respect, an illustrative example is the 2006 Bolivian Gas Crisis during which Brazil took the lead to prioritize regional stability and integration to the benefit of the small states in the area(Guimarães and Maitino, 2017: 12-16). Its socalled "Ethanol Diplomacy", in southern and western African countries is another case in point(Fulquet and Pelfini, 2015: 124). At the same time, Brazil aiming for energy independence keeps increasing the share of renewable energy sources in its primary energy mix, thereby fostering its reputation as a "green energy power"(Guimarães and Piefer, 2017: 1-5).

As a whole, Brazil's rise to a higher power status depends on its ability to take advantage of its energy wealth to invest in education, technology and infrastructure, in order to achieve economic growth and sustainable development(Brainard and MartinezDiaz, 2009: 3). What is more, the new energy discoveries give it additional credentials to promote itself as a responsible, credible and respectful power in the region and the world(Gardini, 2016: 15-16). Further energy revenues can perfectly support its national aspirations, insofar as "globally, Brazil is no revisionist power but aims at a join the club strategy"(Gardini, 2016: 15). Brazilian energy market may play a leading role in building regional energy security and, by extension, accelerating the process of energy integration in Latin America(De Oliveira, 2010).

As for India, to come full circle, its economic growth has made it the third biggest energy consumer in the world. According to EIA's estimates, the world's energy consumption will rise by $28 \%$ by 2040 , with China, India and the other non-OECD Asian countries accounting for nearly two-thirds of this growth(Doman, 2017). As oil and gas demand is expected to reach 607 million metric tons in 2040, India's energy security is pivotal for its growth pace. It has already introduced reforms to exploit its unconventional hydrocarbon fields and invite worldwide enterprises to invest in domestic exploration and production(Capital Market, 2018). To this end, India has adopted a multi-dimensional 
cooperation policy to take advantage of exporters' antagonism in order to get better deals and prices. In 2018, for example, Indian Gail Ltd., the country's largest state gas supplier, negotiated to import 2,5 million tons of LNG from the Russian Gazprom and 5,8 million tons from the US(Reuters, 2018a); and ONGC, India's biggest energy company, signed a partnership agreement with Norway's Statoil local deep-water exploration(Bhaskar, 2018). At the same time, India strengthens its relations with the Persian Gulf states. As ONGC has acquired a 10\% stake in the Gulf's Lower Zakum offshore oil and gas supergiant field with a 40-year deal, talks are in progress with Saudi Aramco and Abu Dhabi's National Oil Company for the construction of a giant oil refinery in India(Gnana, 2018). In addition, India tries to keep balanced relations with Iran. As India is Iran's second largest buyer of oil, in September 2018, following US sanctions against Tehran, it started replacing Iranian oil with crude oil from the US. But later, having cut them by a third, it was granted a waiver to continue Iranian oil imports(Bloomberg, 2018).

In view of these developments, India's energy security policy builds on four main pillars: i) investment in energy fields abroad, ii) construction of gas and oil local infrastructure (pipelines - refineries), iii) conclusion of bilateral energy and iv) active promotion of energy diplomacy in the support of the aforementioned three pillars(Dasgupta, 2018: 5-6). Inasmuch as China's influence via its Belt and Road Initiative strategies seems to have already surpassed India's in Central Asia and countries such as Kazakhstan, Turkmenistan and Uzbekistan, the maritime energy corridors get vital importance for India(Smith Stegen, 2015: 200-201). From this angle, the command of the sea routes in the Indian Ocean has become a common area of paramount interest. While China appears to have adopted an assertive attitude, India proves unprepared to play its part as an influential naval power. Thus, taking advantage of US preference for it to take on a regional leadership role, India has developed a "naval diplomacy" strategy for issues such as piracy and Islamic fundamentalism, in order to gain time and counterbalance China(Dasgupta, 2018: 14-15). Today's Indian naval force consists of 140 warships and 220 aircraft, with 32 ships and submarines being under construction in Indian shipyards. According to Delhi's 10-year shipbuilding program, another 56 warships and six submarines will be added to its battle fleet. Overall India plans to acquire a world-class navy made up of 200 ships and 500 aircrafts by 2050(Woody, 2018).

Clearly, India's energy security policy is driven by its increasingly growing energy demands. What is more, holding constant the US-India navy-to-navy cooperation(Mishra, 2019), the development of its naval force cannot be seen in isolation from its aspiration to become a South Asian regional power in its rivalry with China "from the mountains to the sea"(Noone, 2018). Insofar as India is on its way to become a global superpower, attaining an energy status is a necessary step to take to this end(Drobot, 2018; FE Online, 2018). Now, we turn to the EU. 


\section{The EU in the new energy landscape}

As mentioned, the emerging global energy landscape is intertwined, if not driven, by similar rearrangements in world politics. This dynamic has resulted in developments that, as the comparative analysis of China, Brazil and India demonstrates, make incompatible the national interests of major state actors, who urgently need to make proper adjustments. This section examines whether or not the energy priorities of EU memberstates are compatible, and to what extent they are likely to undermine or foster the EU's global performance as a single actor(Kustova, 2017).

The fall of oil prices during 2015 to 2016 did not affect the same EU member states. It benefited minor EU economies such as Bulgaria, Estonia, Slovakia, Croatia, Poland, Portugal, Estonia, Finland, and Greece that are still oil-intense economies(Kasek and Boratyński, 2016). In a sense, this was a sign that the EU's economy might reduce its dependence on oil. For some analysts, it could also be a sign of its low global competitiveness(Kasek and Boratyński, 2016: 13). Either way, the gist of the matter is that the variation in impact of the falling oil prices on EU member states demonstrates not only the diversity of energy structures and needs in EU economy but also the mismatch thereof.

In the 2010s the EU faced multidimensional crises that are still testing its cohesion. The outbreak of the economic crisis found countries such as Greece and Italy in turmoil and in open dispute with EU institutions(Lapavitsas et al., 2010). Brexit has made the once unthinkable happen; that is the probability of a member-state leaving the EU, thereby distorting the idea and the ensuing narrative of the smooth, linear progression of the European integration process(Kelemen, 2013). The migration crisis has pushed to center stage once non-influential or overlooked groups of member-states such as the Visegrad Group (V4) consisting of the Czech Republic, Hungary, Poland, and Slovakia(Cabada and Waisová, 2018). In one or another way, these crises appear to permeate and interrelate with a variety of energy related issues directly confronting with some aspects of the general EU's energy security policy.

The EU is a net energy products importer. In the first semester of 2018, its oil and natural gas imports accounted for $70 \%$ and $20 \%$ of its total consumption respectively. Russia remains the EU's largest supplier of natural gas and oil, followed by Norway. Imports from these two countries basically account for over half and more than $40 \%$ of the EU's gas and oil needs respectively(Eurostat, 2018). As a whole, the EU imports 54\% of its consumed energy, which accounts for $20 \%$ of its overall imports(European Commission, n.d.).

In this context, today's EU energy security policy aims to i) set up an integrated energy market to enhance affordability and competitiveness, and ii) secure energy supply and sustainability(Gouardères, 2018). To this end EU energy strategies are epitomized by the Energy Union strategy, the 2030 Framework for Climate and Energy and the European Energy Security Strategy(European Commission, 2014: 15-19). Reducing dependence from Russian energy supplies by creating a highly competitive energy market stands as the cornerstone of the EU's energy security strategy(New Europe Online/KG, 
2018). In essence, the Treaty of Lisbon and the Third Energy package consist in the main institutional framework for EU energy governance(Szulecki et al., 2016). Hence legislation has already introduced to attain such targets as supply diversification, increasing energy production in the EU, speaking with one voice in external energy policy, the 2030 energy and climate goals ( $40 \%$ cuts in greenhouse gas emissions, at least $27 \%$ share for renewable energy, at least $27 \%$ improvement in energy efficiency) and the 2050 goal of reducing greenhouse gas emissions to 80-95\% below the 1990 levels(European Commission, n.d.).

In terms of world politics, the EU seeks to play a preponderant role in advancing renewable energies and become the global leader in combating climate change, a goal being at the core of its international security and foreign policy(Parker et al., 2017). Portraying itself as a market, normative or regulatory power, it pursues not merely to regulate its internal market along liberal, market-based lines but also to promote its regulatory framework globally(Damro, 2012; Young, 2015).

Nonetheless, the latest crises in the EU has cast doubts on its ability to perform as a single, unified actor voicing a common view in global energy politics. Evidence show that its energy security policy is subverted by its member-states' different perceptions, priorities and aspirations in regional and international level.

Greece, for example, tried twice to boost its economy by promoting energy related issues before and after its debt crisis. The deals with Russia for the construction of the Burgas-Alexandropoulis oil pipeline and the South Stream gas pipeline in 2006-2009 could be significant assets for handling its financial and economic problems(Jirušek et al., 2017: 349). They were also compatible with its aspiration to become a regional energy hub with pipelines bypassing Turkey, a traditional problematic neighbor(UPI, 2009). At the outset, the EU was not negative towards these projects. But later, the escalation of Russia-Ukraine conflict, the disruptions of Russian gas flows to Europe, the US's opposition and the efforts of the EU to diversify away from Russian energy supplies, all resulted in the cancellation of the projects, thereby negating Greek efforts to make profit out them(Christou, 2011). After the Greek sovereign debt crisis erupted in 2010, the renewable resources project "Helios", which envisages the production of solar energy, was designed by Greek authorities in cooperation with the Troika institutions (European Commission, ECB, IMF) to help Greece reimburse its EU creditors(Kathimerini, 2011). The EU, however, shied away from actively supporting the project, even though the promotion of renewable energy was at the core of its energy security policy and strategies. The result was that "Helios" ended up in failure(Lenz, 2015).

Italy, the latest breaking issue on the EU's financial scene, is another case in point. Once more the EU's fiscal policies became a matter of dispute and long negotiations with a member-state. Italy's 2019 budget wasn't aligned enough with the European Commission's guidelines(Reuters, 2018b). The clash between the Italian government and the European Commission was fierce and the Eurozone's cohesion was tested(Bartz et al., 2018). After mutual compromises, a deal was reached in December 2018(BBC, 2018). Analogous disagreements can be observed in EU-Italy relations on energy issues 
in which the US was involved as well. Throughout the 1970s Italy, keeping an eye on its energy security, cooperated with the Soviet Union to secure natural gas supplies despite the US's opposition. In the 1990s, Italy continued energy cooperation with Libya, despite UN and US sanctions and later in 2007 it agreed with Russia over the construction of the South Stream pipeline against the EU-backed Nabucco-West project(Prontera, 2018: 1117). In the 2010s, Italy set out to become an "energy hub" for the EU. But the EU's Energy Union strategy contrasted these plans that required of Italy to build a very different nexus of supply agreements(Prontera, 2018: 25-26). Brexit is another thorn in EU side, as it has also an energy dimension in relation to EU energy security policy. Surveys showed that, though acknowledging positive effects, many UK citizens preferred an "energy independence" national strategy to a common EU energy policy as a way to protect their discrete national identity(Batel and DevineWright, 2018: 43). The UK was reported to have lobbied against EU stronger regulations on energy efficiency and renewable energy resources(Fredriksson et al., 2018: 13). Indeed, some classified documents that leaked indicated that the UK wanted a lower than 30 percent energy efficiency target set by the EU until 2030, and tried to avoid energy selling cuts that had to be applied by its energy companies during the next decade(Vaughan, 2017). Fracking was an additional hot topic for the EU in 2014. The UK and Poland were strongly supportive of the launch of shale exploitation, while mainly France, Germany and Spain were against; finally the former blocked the EU's legislation(Keating, 2014). Clearly, the UK aspired to have a more upgraded role in the EU's energy policy formulation, in line with its national priorities and preferences.

The issue of fracking brings us to the V4, which have been dynamically reactivated during the migration crisis in the EU. The V4 is strongly opposing EU refugee flows burden sharing efforts(Maricut, 2017: 171). But beside it, Poland is said to have capitalized on the Group to promote its own energy security agenda(Cabada and Waisová, 2018: 14). Being a fossil-fuel reliant economy, it wants to achieve "energy independence" from Russia by way of nuclear power and renewable energy development, and US LNG imports(Zajączkowska, 2018: 324-326). But in any case as it is one of the world's largest coal producers, it doesn't want to stop exploiting its abundant coal resources(Furfari, 2017).

Even more, Poland strongly favors fracking, with Donald Tusk, its former President who today is the President of the European Council, declaring in 2012 that "after years of dependence on our large neighbor (Russia), today we can say that my generation will see the day when we will be independent in the area of natural gas and we will be setting terms"; a statement that clearly indicated Poland's traditionally opposing attitude towards Russia as well(Daly, 2012). France, on the other hand, is one of the most eminent opponents of fracking in the EU, although it possesses the biggest shale oil basin in Europe(Grealy, 2016). As it is Europe's leading nuclear power producer, it has ample time to adjust without having major energy security concerns(Katona, 2018). Fracking is still an open question in the EU, with member-states having different positions and leaving supporters such as Poland to block EU regulation(DTE Staff, 2018). 
Generally speaking about EU energy security issues, the case of Poland meets the recent Germany's agreement with Russia on the construction of the Nord Stream 2 gas pipeline. This deal, having provoked a fiery reaction from the US threatening Germany with sanctions, has undermined EU strategy for reducing Russian supply dependence(Reuters, 2019). Nord Stream 2 might prove a critical danger for Ukraine and a straight threat for Poland in economic and political terms(Wojcieszak, 2017: 89). In essence, the EU's lack of determination to take a clear position, as it did in the case of Greek agreements with Russia, might disclose the great imbalances in power between its member-states(Maull, 2018). The contrast between the member-states' national energy interests and the EU's energy security policy priorities is more than evident in many respects: i) Poland and most Central European members that are afraid of Russian power strongly oppose the project, ii) Ukraine is likely to lose transit revenues that are vital for its economy, iii) European dependence on Russian gas may increase, iv) Germany, Austria, and France support the project with energy criteria market rhetoric and v) the EU risks its relations with the US(Archick, 2018: 18).

In terms of projecting power, too, the recent case of Cyprus' natural gas reserves exploitation is indicative(Leigh, 2014: 4). When Turkey started harassing international companies' operations, it was the U.S. Navy that arrived in the region to monitor and prevent the outbreak of skirmishes at sea(MarEx, 2018). On the contrary, the EU confined its reaction merely to an array of public declarations by Juncker, Tusk and Mogherini(Mogherini, 2018). From this angle, thus, of the US and the EU, who matters more in global energy politics is a question that is easily addressed.

Several analysts, to come full circle, believe that the EU is hardly considered a major global energy actor by both its member states(Bain et al., 2017: 15) and rising energy states such as China, Brazil and India(Chaban et al., 2017: 16-18). Other scholars underline that Russia is learning how "to use EU-regulations in order to avoid EUregulations"(Stergiou, 2018: 224). Along a similar line of reasoning, it is argued that EU market integration, the natural gas hub pricing via LNG installments in Europe and the shale revolution in the US are not enough to secure the EU's gas supplies. EU dependency on Russia for gas supplies is unlikely to change because pipeline gas remains more affordable and the LNG suppliers may find Asian markets more profitable, leaving EU gas hubs in deficiency(Mitrova et al., 2016: 21). Clearly, in order for the EU to become a global energy actor, it should not be confined to its normative power, as this type of power cannot serve its goals in a complex geopolitical context(Escribano Francés, 2011: 54-55). Adhering to the logic of market-oriented energy strategies, creating a common energy market and projecting a regulatory power, all are necessary but insufficient conditions for the EU to underpin the energy interests of its memberstates and evolve into a global energy security power. 


\section{Conclusion}

Last decade's realignment to the global energy landscape should be seen in combination with ongoing "great transformations" in the world order. The difficulty in defining energy security in a unique and widely accepted manner, derives from the complexity of global energy politics and the variety of major actors' energy interests, priorities and aspirations; which, in essence, reflect how these actors address, through and by their own perceptual palette, the energy security riddle facing. Table 1 depicts the main points of our analysis:

\begin{tabular}{|c|c|c|c|c|}
\hline Actor & Energy status goal & World Order Preference & Energy landscape acts & Energy security priorities \\
\hline US & Energy Dominance & Supremacy & Shale Revolution / Net exporter & Energy security exporter \\
\hline Russia & Energy Superpower & Bipolar / US rivalry / Old glory & Energy Pipelines / Long term deals & $\begin{array}{l}\text { Market shares / Security of } \\
\text { demand / Good prices }\end{array}$ \\
\hline Brazil & $\begin{array}{l}\text { Major Energy exporter / Green } \\
\text { energy power }\end{array}$ & G20 / Developing countries leader & $\begin{array}{l}\text { Exploit local resources / Ethanol } \\
\text { Diplomacy }\end{array}$ & $\begin{array}{c}\text { Regional energy integration / } \\
\text { Renewables }\end{array}$ \\
\hline India & Energy diplomacy player & $\begin{array}{c}\text { Multipolar / Regional - major player / } \\
\text { China rivalry }\end{array}$ & $\begin{array}{c}\text { Energy Investments abroad / Domestic } \\
\text { Refineries / Oil imports from Iran / Solar } \\
\text { Energy }\end{array}$ & $\begin{array}{c}\text { World's private investors call / } \\
\text { Domestic resources / Worldclass } \\
\text { Navy }\end{array}$ \\
\hline
\end{tabular}

Table 1 The Major Energy Actors Perceptions of the Energy Security Riddle

The shale revolution in the US has been a decisive development. Every major energy actor has been forced to align its perception of its energy security policy and its global energy role with the US's energy policy choices and actions. Crude oil and LNG exports directly challenges the efforts both of OPEC to manipulate markets and of Russia to leverage its abundant oil and gas resources to enhance its influence especially towards Europe. The US's decision to withdraw from the Paris agreement is a clear aftereffect of these developments signifying its determination to assure its supremacy in world politics.

Also, Russia, China, Brazil and India try to concert their energy ambitions with their particular view of the world order. Putin's Russia pursues its energy superpower vision to restore the glory of the past and regain its position as the one pole of a bipolar system. China, Brazil and India, following their own but different approaches to energy security issues, aspire to claim their share of influence in a multipolar world. Essentially, Russia and the other rising powers concerned, seek to attain the "energy status goal"; an achievement that is destined to pave the way for enhancing their growth rates and global power reach. 
The EU, finally, has been long discussed whether it is able to act as a full political actor on the world stage and speak with one voice internally and externally(Krotz, 2009). The new energy landscape and its ensuing challenges seem to be another test for this ability. The EU's perceptual palette and energy aims are quite different from those of other major players. The problem however is that the EU's energy security priorities are incompatible with those of its member-states as well. Evidence shows that both the EU and its member states address the energy security riddle in different ways; a development that is likely to cause crevasses to the EU's efforts to perform as a single global energy actor. What is more, the EU's proclaimed regulatory / normative power proves weak or unable to protect, serve and enhance its own and its member-states' energy related interests. But the elaboration of this finding might be the subject of another research.

\section{References}

Abbott K (2016) Understanding and Countering Hybrid Warfare: Next Steps for the North Atlantic Treaty Organization. Available at: http://ruor.uottawa.ca/handle/10393/34813 (accessed 28 September 2018).

AFP (2018) State-owned oil company Petrobras: Brazil's crown jewel - ET EnergyWorld. Available at: https://energy.economictimes.indiatimes.com/news/oil-andgas/stateowned-oil-company-petrobras-brazils-crown-jewel/66289931 (accessed 10 January 2019).

Archick K (2018) The European Union: Ongoing Challenges and Future Prospects (version 18). Congressional Research Service (CRS): 30.

Bain J, Greenland B, Knodt M, et al. (2017) A polyphonic marketplace: Images of EU external energy relations in British, French and German media discourses. Comparative European Politics 15(1): 115-134. DOI: 10.1057/cep.2016.16.

Bartz T, Mahler A, Mayr W, et al. (2018) Weaponized Debt: Italy Doubles Down on Threat to Euro Stability. Spiegel Online, 1 November. Available at: http://www.spiegel.de/international/europe/blackmail-from-italy-could-createnexteuro-crisis-a-1235928.html (accessed 16 January 2019).

Batel S and Devine-Wright P (2018) Populism, identities and responses to energy infrastructures at different scales in the United Kingdom: A post-Brexit reflection. Energy Research \& Social Science 43: 41-47. DOI: 10.1016/j.erss.2018.05.011.

BBC (2018) Italy strikes budget deal with EU. Available at: https://www.bbc.com/news/worldeurope-46620853 (accessed 16 January 2019).

BBC news (2016) Non-Opec states agree to cut oil output. 10 December. Available at: https://www.bbc.com/news/business-38276667 (accessed 13 January 2019). 
Behar A and Ritz RA (2016) An Analysis of OPEC's Strategic Actions, US Shale Growth and the 2014 Oil Price Crash. Working Paper No. 16/131. IMF. Available at:

http://public.eblib.com/choice/publicfullrecord.aspx?p=4711591 (accessed 13 January 2019).

Bhaskar U (2018) Statoil eyes partnership with ONGC to re-enter India's hydrocarbon space. Available at:

https://www.livemint.com/Industry/9kojS1ku1C7JPF9iFo0KdJ/Statoileyes-partnershipwith-ONGC-to-reenter-India.html (accessed 15 January 2019).

Bloomberg (2018) US agrees to give oil waivers to India, 7 other nations under Iran sanctions Times of India. Available at:

https://timesofindia.indiatimes.com/business/international-business/us-agrees-togiveoil-waivers-to-india-7-other-nations-under-iransanctions/articleshow/66473353.cms (accessed 15 January 2019).

Brainard L and Martinez-Diaz L (eds) (2009) Brazil as an Economic Superpower?

Understanding Brazil's Changing Role in the Global Economy. Washington, D.C: Brookings Institution Press.

Cabada L and Waisová Š (2018) The Visegrad Group as an Ambitious Actor of (Central)European Foreign and Security Policy. Politics in Central Europe 14(2): 9-20. DOI:

10.2478/pce-2018-0006.

Capital Market (2018) India Presently 3rd Largest Energy Consumer In World. Available at: https://www.business-standard.com/article/news-cm/india-presently-3rd-largestenergyconsumer-in-world-118111300715_1.html (accessed 15 January 2019).

Chaban N, Knodt M and Verdun A (2017) 'Talking with' not 'talking at'? Perceptions of the EU as a global normative energy actor in the eyes of BRICS and EU 'Big 3'. Comparative European Politics 15(1): 1-22. DOI: 10.1057/cep.2016.11.

Charokopos M and Dagoumas A (2018) State Capitalism in Time: Russian Natural Gas at the Service of Foreign Policy. Europe-Asia Studies: 1-21. DOI: 10.1080/09668136.2018.1448367.

Christensen SF and Xing L (2016) Emerging Powers, Emerging Markets, Emerging Societies: Global Responses. In: Christensen SF and Xing L (eds) Emerging Powers, Emerging Markets, Emerging Societies: Global Responses. International Political Economy Series. London: Palgrave Macmillan UK, pp. 259-267. DOI: 10.1007/978-1-13756178-7_11.

Christou G (2011) Bilateral Relations with Russia and the Impact on EU Policy: The Cases of Cyprus and Greece. Journal of Contemporary European Studies 19(2): 225-236. DOI: 10.1080/14782804.2011.580911.

Cohen A (2018) OPEC Is Dead, Long Live OPEC+. Available at: 
https://www.forbes.com/sites/arielcohen/2018/06/29/opec-is-dead-longliveopec/\#292ee1ce2217 (accessed 13 January 2019).

Crooks E (2015) The US shale revolution. Available at: https://www.ft.com/content/2ded7416-e930-11e4-a71a-00144feab7de (accessed 11 January 2019).

Daly J (2012) Poland Gives Green Light to Massive Fracking Efforts. Available at: https://oilprice.com/Energy/Natural-Gas/Poland-Gives-Green-Light-toMassiveFracking-Efforts.html (accessed 16 January 2019).

Damro C (2012) Market power Europe. Journal of European Public Policy 19(5): 682-699. DOI:

$$
\text { 10.1080/13501763.2011.646779. }
$$

Dasgupta A (2018) India's Strategy in the Indian Ocean Region: A Critical Aspect of India's Energy Security. Jadavpur Journal of International Relations 22(1): 39-57. DOI: 10.1177/0973598418757817.

De Oliveira A (2010) Energy Security in South America: The role of Brazil. Available at: https://www.iisd.org/library/energy-security-south-america-role-brazil (accessed 14 January 2019).

Doman L (2017) EIA projects 28\% increase in world energy use by 2040 - Today in Energy U.S. Energy Information Administration (EIA). Available at: https://www.eia.gov/todayinenergy/detail.php?id=32912 (accessed 15 January 2019).

Doman L and Kahan A (2018) United States remains the world's top producer of petroleum and natural gas hydrocarbons - Today in Energy - U.S. Energy Information Administration (EIA). Available at: https://www.eia.gov/todayinenergy/detail.php?id=36292 (accessed 11 January 2019).

Downie C (2015) Global energy governance: do the BRICs have the energy to drive reform? International Affairs 91(4): 799-812. DOI: 10.1111/1468-2346.12338.

Drobot GA (2018) The Indian Factor of the World Politics. IOP Conference Series: Materials Science and Engineering 463(4): 042094. DOI: 10.1088/1757-899X/463/4/042094.

DTE Staff (2018) Ireland becomes the fourth EU country to ban fracking. Available at: https://www.downtoearth.org.in/news/energy/ireland-becomes-the-fourth-eucountry-toban-fracking-61091ref=true (accessed 16 January 2019).

Dunn DH and McClelland MJL (2013) Shale gas and the revival of American power: debunking decline? International Affairs 89(6): 1411-1428. DOI: 10.1111/14682346.12081 . 
Escribano Francés G (2011) Market or geopolitics? The Europeanization of EU's energy corridors. Psarras J (ed.) International Journal of Energy Sector Management 5(1): 3959. DOI: 10.1108/17506221111120893.

\section{European Commission (2014) COMMUNICATION FROM THE COMMISSION TO THE EUROPEAN}

PARLIAMENT AND THE COUNCIL European Energy Security Strategy /* COM/2014/0330 final */. Available at: https://eurlex.europa.eu/legalcontent/EN/ALL/?uri=CELEX:52014DC0330\&qid=140785561156 6 (accessed 27 January 2019).

European Commission (n.d.) Energy Security Strategy. Available at: https://ec.europa.eu/energy/en/topics/energy-strategy-and-energyunion/energysecurity-strategy (accessed 16 January 2019a).

European Commission (n.d.) Imports and secure supplies. Available at: https://ec.europa.eu/energy/en/topics/imports-and-secure-supplies (accessed 16 January 2019b).

Eurostat (2018) EU imports of energy products - recent developments - Statistics Explained. Available at:

https://ec.europa.eu/eurostat/statisticsexplained/index.php/EU_imports_of_energy_prod ucts_-

_recent_developments\#Overview (accessed 16 January 2019).

FE Online (2018) This is where India could become a global superpower soon, and World Bank is vouching for it. Available at: https://www.financialexpress.com/economy/thisiswhere-india-could-become-a-global-superpower-soon-and-world-bank-isvouchingfor-it/1139752/ (accessed 15 January 2019).

Forest D (2017) India Just Became The World's Newest Energy Superpower. In: ValueWalk. Available at: https://www.valuewalk.com/2017/07/india-just-became-worldsnewestenergy-superpower/ (accessed 10 January 2019).

Fredriksson G, Roth A, Tagliapetra S, et al. (2018) Brexit and Energy Policy: Workshop proceedings. Directorate- General for Internal Policies: 44.

Fulquet G and Pelfini A (2015) Brazil as a new international cooperation actor in sub-Saharan Africa: Biofuels at the crossroads between sustainable development and natural resource exploitation. Energy Research \& Social Science 5: 120-129. DOI: 10.1016/j.erss.2014.12.018.

Furfari S (2017) Seeking energy security, Poland welcomes US natural gas but defends coal power. Available at: http://theconversation.com/seeking-energy-securitypolandwelcomes-us-natural-gas-but-defends-coal-power-78704 (accessed 16 January 2019). 
Gardini GL (2016) Brazil: What Rise of What Power?: Brazil: What Rise of What Power? Bulletin of Latin American Research 35(1): 5-19. DOI: 10.1111/blar.12417.

Gardini GL and Almeida MHT de (eds) (2016) Foreign Policy Responses to the Rise of Brazil: Balancing Power in Emerging States. Palgrave studies in international relations series. Houndmills, Basingstoke, Hampshire; New York, NY: Palgrave Macmillan.

Ghimire S (2018) Rising powers and security: a false dawn of the pro-south world order? Global Change, Peace \& Security 30(1): 37-55. DOI:

10.1080/14781158.2018.1431878.

Gnana JGJ (2018) Adnoc and Aramco to partner on \$44bn Indian refinery. Available at: https://www.thenational.ae/business/energy/adnoc-and-aramco-to-partner-on44bnindian-refinery-1.744105 (accessed 15 January 2019).

Goldthau A and Sitter N (2015) Soft power with a hard edge: EU policy tools and energy security. Review of International Political Economy 22(5): 941-965. DOI: 10.1080/09692290.2015.1008547.

Gong X (2018) The Belt \& Road Initiative and China's influence in Southeast Asia. The Pacific Review: 1-31. DOI: 10.1080/09512748.2018.1513950.

Gouardères F (2018) Energy policy: general principles | Fact Sheets on the European Union | European Parliament. Available at: http://www.europarl.europa.eu/factsheets/en/sheet/68/energy-policy-generalprinciples (accessed 16 January 2019).

Grealy N (2016) France bans fracking but imports shale oil. Available at: https://energypost.eu/france-can-square-ban-fracturing-import-shale-oil/ (accessed 16 January 2019).

Guimarães C and Piefer N (2017) Brazil: (Future) green energy power and strategic partner for the EU? Comparative European Politics 15(1): 23-44. DOI: 10.1057/cep.2016.12.

Guimarães F de S and Maitino ME (2017) Socializing Brazil into Regional Leadership: The 2006 Bolivian Gas Crisis and the Role of Small Powers in Promoting Master Roles Transitions. Foreign Policy Analysis. DOI: 10.1093/fpa/orx010.

Hopewell K (2015) Different paths to power: The rise of Brazil, India and China at the World Trade Organization. Review of International Political Economy 22(2): 311-338. DOI: 10.1080/09692290.2014.927387.

Ichord RF (2018) US Nuclear-Power Leadership and the Chinese and Russian Challenge. 1 March. Atlantic Council. Available at: https://www.jstor.org/stable/resrep16816 (accessed 14 January 2019). 
Jaganathan J (2018) China overtakes Japan as world's top natural gas importer. Reuters, 12 November. Available at: https://www.reuters.com/article/china-japanlngidUSL4N1XN3LO (accessed 14 January 2019).

Jirušek M, Vlček T and Henderson J (2017) Russia's energy relations in Southeastern Europe: an analysis of motives in Bulgaria and Greece. Post-Soviet Affairs 33(5): 335-355.

DOI:

10.1080/1060586X.2017.1341256.

Kapitonov I (2018) Peculiarities of Applying the Theory of International Business by Russian Oil and Gas Companies. Space and Culture, India 6(4). DOI: 10.20896/saci.v6i4.378.

Karlsson R (2018) The high-energy planet. Global Change, Peace \& Security 30(1): 77-84.

DOI:

10.1080/14781158.2018.1428946.

Kasek L and Boratyński J (2016) Low Oil Prices : Long-Term Economic Effects for the EU and Other Global Regions Based on the Computable General Equilibrium PLACE Model. EcoMod2016 9319, 4 July. EcoMod. Available at: https://ideas.repec.org/p/ekd/009007/9319.html (accessed 15 January 2019).

Kathimerini (2011) Greece to use revenue from solar project to pay debt, EU says |

Kathimerini. Available at:

http://www.ekathimerini.com/136850/article/ekathimerini/news/greece-to-userevenuefrom-solar-project-to-pay-debt-eu-says (accessed 16 January 2019).

Katona V (2018) Can France Move Away From Nuclear Energy? Available at: https://oilprice.com/Alternative-Energy/Nuclear-Power/Can-France-Move-AwayFromNuclear-Energy.html (accessed 16 January 2019).

Keating D (2014) Poland offers incentives for fracking. Available at: https://www.politico.eu/article/poland-offers-incentives-for-fracking/ (accessed 16 January 2019).

Kelemen RD (2013) Saving the Euro, Dividing the Union. Foreign Affairs, 21 January. Available at: http://www.foreignaffairs.com/articles/138768/r-daniel-kelemen/savingthe-eurodividing-the-union (accessed 3 July 2014).

Kennedy AB (2015) China and the Free-Rider Problem: Exploring the Case of Energy Security: CHINA AND ENERGY SECURITY. Political Science Quarterly 130(1): 27-50. DOI: 10.1002/polq. 12286.

Kratochvíl P and Tichý L (2013) EU and Russian discourse on energy relations. Energy Policy 56: 391-406. DOI: 10.1016/j.enpol.2012.12.077.

Krickovic A (2015) When Interdependence Produces Conflict: EU-Russia Energy Relations as a Security Dilemma. Contemporary Security Policy 36(1): 3-26. DOI: 10.1080/13523260.2015.1012350. 
Krotz U (2009) Momentum and Impediments: Why Europe Won't Emerge as a Full Political Actor on the World Stage Soon*. JCMS: Journal of Common Market Studies 47(3): 555-578. DOI: 10.1111/j.1468-5965.2009.01815.x.

Kustova I (2017) Towards a comprehensive research agenda on EU energy integration: policy making, energy security, and EU energy actorness. Journal of European Integration 39(1): 95-101. DOI: 10.1080/07036337.2017.1258757.

Lapavitsas C, Kaltenbrunner A, Lindo D, et al. (2010) Eurozone crisis: beggar thyself and thy neighbour. Journal of Balkan and Near Eastern Studies 12(4): 321-373. DOI: 10.1080/19448953.2010.510012.

Larsen JA, Breedlove PM, Lasconjarias G, et al. (2015) NATO's Response to Hybrid Threats. Rome: NATO Defense College.

Leigh M (2014) Energy - A Geopolitical Game Changer? The International Spectator 49(2): 110. DOI: $10.1080 / 03932729.2014 .906929$.

Lenz K-F (2015) Another Tragedy In Greece. Available at: https://cleantechnica.com/2015/07/02/another-tragedy-in-greece/ (accessed 16 January 2019).

Lind J and Press DG (2018) Markets or Mercantilism? How China Secures Its Energy Supplies. International Security 42(04): 170-204. DOI: 10.1162/isec_a_00310.

Locatelli C, Abbas M and Rossiaud S (2017) The Emerging Hydrocarbon Interdependence between Russia and China: Institutional and Systemic Implications. Europe-Asia Studies 69(1): 157-170. DOI: 10.1080/09668136.2016.1274020.

MarEx (2018) U.S. Navy Arrives as Exxon Begins Cyprus Campaign. Available at: https://www.maritime-executive.com/article/u-s-navy-arrives-as-exxon-beginscypruscampaign (accessed 17 January 2019).

Maricut A (2017) Different narratives, one area without internal frontiers: why EU institutions cannot agree on the refugee crisis. National Identities 19(2): 161-177. DOI: 10.1080/14608944.2016.1256982.

Maull HW (2018) Reflective, Hegemonic, Geo-economic, Civilian ... ? The Puzzle of German Power. German Politics 27(4): 460-478. DOI: 10.1080/09644008.2018.1446520.

Mishra V (2019) India-US maritime cooperation: Crossing the Rubicon. Maritime Affairs: Journal of the National Maritime Foundation of India 0(0): 1-11. DOI: 10.1080/09733159.2018.1562453.

Mitrova T, Boersma T and Galkina A (2016) Some future scenarios of Russian natural gas in Europe. Energy Strategy Reviews 11-12: 19-28. DOI: 10.1016/j.esr.2016.06.001.

Mogherini F (2018) Answer to Question No E-001721/18. Available at: 
http://www.europarl.europa.eu/doceo/document//E-8-2018-001721-ASW_EN.html (accessed 17 January 2019).

Moore S (2017) Energy independence in America can be achieved. Available at:

//www.washingtontimes.com/news/2017/jul/2/energy-independence-in-americacan-beachieved/ (accessed 23 January 2018).

New Europe Online/KG (2018) EU strives to reduce energy import dependency. In: New Europe. Available at: https://www.neweurope.eu/article/eu-strives-reduceenergyimport-dependency/ (accessed 16 January 2019).

Noone BT (2018) India's rivalry with China, from the mountains to the sea. Available at: https://www.lowyinstitute.org/the-interpreter/doklam-india-rivalry-china-mountainssea (accessed 15 January 2019).

OPEC (2008) OPEC : Energy Security and Supply. Available at: https://www.opec.org/opec_web/en/862.htm (accessed 13 January 2019).

OPEC (2018) OPEC : OPEC 175th Meeting concludes. Available at: https://www.opec.org/opec_web/en/press_room/5278.htm (accessed 13 January 2019).

O'Sullivan ML (2017) Windfall: How the New Energy Abundance Upends Global Politics and Strengthens America's Power. New York; London: Simon \& Schuster.

Paraskova T (2018) Brazil Eyes \$30 Billion Offshore Oil Boom. Available at: https://oilprice.com/Energy/Crude-Oil/Brazil-Eyes-30-Billion-Offshore-Boom.html (accessed 14 January 2019).

Parker CF, Karlsson C and Hjerpe M (2017) Assessing the European Union's global climate change leadership: from Copenhagen to the Paris Agreement. Journal of European Integration 39(2): 239-252. DOI: 10.1080/07036337.2016.1275608.

President Speech (2017) Remarks by President Trump at the Unleashing American Energy event. Available at: https://www.whitehouse.gov/briefingsstatements/remarkspresident-trump-unleashing-american-energy-event/ (accessed 22 January 2018).

Proedrou F (2017) A new framework for EU energy security: putting sustainability first. European Politics and Society 18(2): 182-198. DOI: 10.1080/23745118.2016.1215374.

Proedrou F (2018) Russian Energy Policy and Structural Power in Europe. Europe-Asia Studies 70(1): 75-89. DOI: 10.1080/09668136.2017.1419169.

Prontera A (2018) Italian energy security, the Southern Gas Corridor and the new pipeline politics in Western Europe: from the partner state to the catalytic state. Journal of International Relations and Development 21(2): 464-494. DOI: 10.1057/jird.2015.31. 
Reeves J (2018) China's Silk Road Economic Belt Initiative: Network and Influence Formation in Central Asia. Journal of Contemporary China 27(112): 502-518. DOI:

10.1080/10670564.2018.1433480.

Reuters (2018a) India's GAIL renegotiates LNG deal with Gazprom. Available at: https://www.reuters.com/article/gail-gazprom-lng-idUSL3N1PB3UK (accessed 15 January 2019).

Reuters (2018b) Italy budget crisis averted after EU agreement. Available at: https://www.euronews.com/2018/12/19/italy-budget-crisis-averted-after-euagreement (accessed 16 January 2019).

Reuters (2019) U.S. sanctions against Nord Stream 2 wrong solution: Germany's Maas.

Available at: https://www.reuters.com/article/us-germany-russiapipelineidUSKCN1P42IH (accessed 16 January 2019).

Rühle M (2012) NATO and energy security: from philosophy to implementation. Journal of Transatlantic Studies 10(4): 388-395. DOI: 10.1080/14794012.2012.734673.

Rühle M (2015) NATO and the Ukraine Crisis. American Foreign Policy Interests 37(2): 8086. DOI: $10.1080 / 10803920.2015 .1038925$.

Rutland P (2015) Petronation? Oil, gas, and national identity in Russia. Post-Soviet Affairs 31(1): 66-89. DOI: 10.1080/1060586X.2014.952537.

Sartori N (2014) Geopolitical Implications of the US Unconventional Energy Revolution. The International Spectator 49(2): 66-82. DOI: 10.1080/03932729.2014.906955.

Siddi M (2018) The Role of Power in EU-Russia Energy Relations: The Interplay between Markets and Geopolitics. Europe-Asia Studies: 1-20. DOI: 10.1080/09668136.2018.1536925.

Skalamera M (2018) Explaining the 2014 Sino-Russian Gas Breakthrough: The Primacy of Domestic Politics. Europe-Asia Studies 70(1): 90-107. DOI:

10.1080/09668136.2017.1417356.

Smith Stegen K (2015) Understanding China's global energy strategy. C. Lattemann and Professor W. Zhang D (ed.) International Journal of Emerging Markets 10(2): 194-208. DOI: 10.1108/IJOEM-04-2014-0059.

Sookhan A (2018) The development of Brazil's gas resources and the impact on external gas supplies. Available at: https://www.gecf.org/events/the-developmentofbrazil\%E2\%80\%99s-gas-resources--the-impact-on-external-gas-supplies (accessed 14 January 2019).

Sovacool BK (ed.) (2011) The Routledge Handbook of Energy Security. London ; New York: Routledge. 
S\&P Global Platts (2018) The New American Revolution: US crude goes global.: 12.

Stergiou A (2017) Energy Wealth as Peace and Democracy Incentive: The Eastern Mediterranean Case. In: Bitros GC and Kyriazis NC (eds) Democracy and an OpenEconomy World Order. Cham: Springer International Publishing, pp. 257-268. DOI: 10.1007/978-3-319-52168-8_16.

Stergiou A (2018) EU-Russia Antagonism in South-Eastern Europe: The Energy Factor. In: Vliamos S and Zouboulakis MS (eds) Institutionalist Perspectives on Development. Cham: Springer International Publishing, pp. 211-233. DOI: 10.1007/978-3-319984940_12.

Szulecki K, Fischer S, Gullberg AT, et al. (2016) Shaping the 'Energy Union'”: between national positions and governance innovation in EU energy and climate policy'. Climate Policy 16(5): 548-567. DOI: 10.1080/14693062.2015.1135100.

Thaler P (2016) The European Commission and the European Council: Coordinated Agenda setting in European energy policy. Journal of European Integration 38(5): 571-585. DOI: 10.1080/07036337.2016.1178252.

The Economist (2014) Sheikhs v shale. The Economist, 4 December. Available at: https://www.economist.com/news/leaders/21635472-economics-oil-havechangedsome-businesses-will-go-bust-market-will-be (accessed 13 May 2018).

The White House (2017) National Security Strategy of the United States of America. Available at: https://www.whitehouse.gov/wp-content/uploads/2017/12/NSS-Final-12-1820170905.pdf (accessed 5 February 2018).

UPI (2009) Greece aims to become energy hub. Available at: https://www.upi.com/Greeceaims-to-become-energy-hub/79701252423800/ (accessed 25 June 2018).

Vaughan A (2017) UK lobbies Europe to dilute flagship energy efficiency law. The Guardian, 28 May. Available at: https://www.theguardian.com/environment/2017/may/28/ukpresses-europe-to-diluteflagship-energy-efficiency-law (accessed 16 January 2019).

Wojcieszak Ł (2017) Nord Stream 2 Pipeline. Role of German-Russian Energy Cooperation for Poland. American Journal of Sociological Research 7(3): 85-89.

Woody C (2018) India is beefing up its navy to counter China's increasingly powerful fleet. Available at: https://www.businessinsider.com/india-is-beefing-up-its-navy-tocounterchinas-powerful-fleet-2018-12 (accessed 10 January 2019).

Yilmaz S and Daksueva O (2019) The energy nexus in China-Russia strategic partnership. International Relations of the Asia-Pacific 19(1): 63-88. DOI: 10.1093/irap/lcx003. 
Young AR (2015) The European Union as a global regulator? Context and comparison. Journal of European Public Policy 22(9): 1233-1252. DOI: 10.1080/13501763.2015.1046902.

Zajączkowska M (2018) The Energy Union and European Union energy security. Ekonomia $i$ Prawo 17(3): 319-328. DOI: 10.12775/EiP.2018.023.

Zhao S (2008) China's Global Search for Energy Security: cooperation and competition in AsiaPacific. Journal of Contemporary China 17(55): 207-227. DOI:

10.1080/10670560701809460. 